have recently been rent asunder by a rift 150 to 200 feet deep, reaching from the summit of the mountain all the way down to the water. Across this rift there is no way of passing, and, in order to reach the south-eastern corner of the slip, it is necessary to scramble up to the top of the mountain, so as to get round the crevasse. It is difficult to form any adequate conception of the titanic grandeur of Nature at this spot. He who has once had the opportunity of viewing it from the precipice of the earth-slip will never forget the impression. Having finished my survey here, we returned to our tent the same way we had come, glad of rest, exhausted with fatigue and want of sleep as we were, after thirty-six hours' continuous travel.

On July 28 I set out on my return journey to Mývatn, taking a direct course across the northern part of Odátahraun to the farmstead of Granavatn, on the southern side of the lake (Mývatn). This I did with a view to rediscovering the whole of the old highway, the eastern end of which I had already traced. First we shaped our course directly for the northern end of Herðubreiðarfjöll, guided by the beacons to which I have alluded already. We crossed a pass, dividing the easternmost neck of the mountains from the main range, in the eastern approach to which an excessively rough lava, split by innumerable rifts, had to be traversed, in which we succeeded by the mode of scrambling. On the verge of one of the rifts in this lava we came upon a dilapidated beacon, and again upon another on the western defile from the pass, from where we threaded our way along the skirts of a recent and very rough lava, directing our course for the central neck of Herðubreiðarfjöll. Here we were intercepted by two enormous rifts, Ioo to I 50 feet deep, divided by an earth-slip one mile broad, and twenty miles long. With the exception of Almannagjá and Hrafnagjá, near Thingvellir, these are the largest rifts in Iceland. Having succeeded in bringing our caravan over the eastern brim down alongside the spurs of an isolated "fell," we charged the western brim in vain for a long time until we came upon a sort of steep pass, up through which we brought our ponies, and found upon the verge three dilapidated beacons, which showed that we were still on the traces of the old highway. From this spot beacons may be still traced in a straight direction for Fremri Námur, but recent rifts and lavas have destroyed the road, which, though I now knew its direction, I could pursue no farther. Here, namely, we thought we had overcome all difficulties, but found soon to our cost that we were mistaken. Some distance to the east of Fremri Námur there is a quite recent-looking lava, very long, but narrow, which evidently has welled out of a lava fissure here in 1875, when, besides Askja, Mývatnsöræfi also were in a state of volcanic activity. This lava is not connected with the well-known more northerly lavas of 1875 , wherefore its existence has been overlooked hitherto; and when Johnstrup constructed his map of the lava of Mývatnsöræfi, he was not aware of the fact that the same rift which gave birth to the northern lavas of 1875 had, further to the south, given existence to this, which measures fully one-half of the others. To the east of this lava the earth is all cut up by bottomless cracks, over which it was truly a breakneck business to pass. Across some we had to urge our ponies to jump, others we passed by means of natural bridges of loose boulders, which frequently gave way. This was travelling with one's life in one's hand, and to me it is the greatest wonder that no harm resulted to man or beast. To attempt crossing this new lava was entirely out of the question, so we had to bend our way southward along its eastern skirts until we might get round its southern spur. At this end of the lava I observed a peculiar rift not more than thirty to forty feet long and three to four inches broad, on which twelve craters were situated, in every way formed and shaped as large craters are generally, but of such miniature dimensions, that they looked as if they had been intended for toys for children; the aperture of most of them was only four to five inches in diameter, that of the largest two feet. These had, however, squirted forth dashes of lava to the distance of sixty feet. When at last we had reached the southern end of the lava, a new trouble intervened in the shape of what appeared to be an endless rift, and utterly impassable. We had therefore to make up our minds to spending the night, or whatever time might be required, in finding a passage across this barrier; and after five hours' weary struggle we at last managed to scramble across where the main crack split up into smaller ones. This was hard work for our ponies, languishing with thirst and with hardly anything to eat; and perhaps only a degree less arduous for us, who in the matter of food and drink were no better off. Having crossed this serious barrier, we came upon a much more even tract of lava, and presently, to our intense relief, struck a pool of water under a snowdrift in a dent in the lava, where, having watered our horses, we treated them to the last scanty remainder of their fodder, and then went on our way. In the early morning we reached the valley called Heilagsdair in Bláfjöll, where we were obliged to pitch our tent in order to give the exhausted animals the benefit of the scanty pasture which a few plots of grass offered. After a few hours' welcome sleep we broke up hastily, a gale of wind with rain and sand-drift having burst upon us in the meanwhile. Our course now lay across the spurs radiating to the eastward from Blafjöll, but such was the violence of the hurricane that it was well nigh impossible to sit on horseback without being blown away, and equally difficult to guard against the despairing animals being blown out of our hands into the howling wilderness. After some really considerable trouble and hardship, we managed to scramble down a precipitous gorge into the upland plateau on which the Lake of Mývatn has found its bed. After having more than once lost our bearings on these lower lava*wilds, we succeeded at last in striking the homestead of Grænavatn, exhausted with our exertions, and were glad of a grateful rest in good beds, after having spent a fortnight in a tent, with our saddles for pillows.

Reykjahlíx, near Mývatn, August 4

TH. THORODDSEN

\section{STORAGE BATTERIES}

THE importance and desirability of an efficient and economical storage battery have been very widely recognised, but it is at the present time pretty generally felt that no existing form of storage battery is perfect, and that they are on the whole extravagant and wasteful to an extent sufficient to more than compensate for their undeniable convenience. It is perfectly certain that their employment has not become at all general, and that they have failed to realise the somewhat sanguine hopes of their early promoters.

It seems worth while to examine into the causes of this partial failure, and to inquire how far the evil opinion held by many practical men concerning our present method of storing electrical energy is justifiable.

One of the main objections is that storage involves a loss of some 50 per cent. of the whole. Now all methods of storing and transmitting energy involve some loss. To say that any particular method involves a loss of 50 or even 90 per cent. is not to condemn it utterly. There are many cases when the convenience of storage outweighs the evil of waste altogether ; three principal ones may be specified.

(I) When the power of the source would be otherwise so completely wasted ihat every fraction of it stored is clear gain. This is the case of much terrestrial water power. The energy of the tides or of Niagara is enormous, and wholly wasted so far as human activity is con- 
cerned; if 50 or even ro per cent. could be stored in such a way as to be conveniently available, it would be of considerable value, and any arrangement capable of effecting this storage could only with injustice be stigmatised as wasteful. The solar energy of the Carboniferous epoch has most of it been wasted; but a small fraction--probably not a millionth per cent.- - has been saved and stored in the Coal-measures. It is possible to abuse the coal for not having stored more, but we find it a useful modicum nevertheless.

(2) A second case when the advantage of storage overbalances the loss is when regularity and continuity of supply is needed, and when the source is irregular and fitful. Wind and wave power illustrate this kind of source; it is manifest that wind power has not been so largely used as it would have been, had it been steady and dependable. A practicable method of storing up its energy and giving it out as wanted would gradually cause it to be very largely employed. This case is also illustrated faintly by a gas-engine or jerky motor of any kind, and the regularity and dependableness of a storage cistern may very well make it desirable to put up with some waste provided it be not excessive. Mechanical devices for approximating to regularity, such as the use of slack driving belts, undoubtedly give rise to a waste of power, and so does any form of regulator. But in the utilisation of artificial forms of power like this, questions of economy become almost pre-eminent; and wastefulness is here a most serious objection, and, it may be, prohibitive defect. At the same time, if the engine is liable to stop, or if it is not always working, some mode of storing energy may be absolutely necessary, whether wasteful or not.

(3) Another case, and to some extent the converse of the last, is when the available source is weak, though continuous, while the power is only needed for a short time, but during that time is required to be great. 'This is exemplified in the operation of pile-driving, where energy is stored in the slowly-raised weight to be suddenly expended on the head of the pile, also in the operation of drawing a bow; or again when a small waterfall or steam-engine, running continuously, is to be utilised for lighting during five or six hours each day: the obviously right plan in such circumstances as these is to store the energy during the hours it is not wanted, and thus virtually to double or treble the power of the source while it is actually in use. Unless, however, the loss occasioned by storage were reasonably small, there would be but small gain in attempting the process in this third case.

It is plainly advantageous to devise a method of storing that shall give out the greater part of what is put in ; but we see by these examples that a reasonable loss may be more than compensated by convenience, regularity, availability, and dependableness. Again, when energy has to be transmitted over great distances, it is in practice difficult or impossible to make the expenditure of energy at one end depend upon and be regulated by its consumption at the other; and so, without some system of storage, great waste will ensue during intervals of small consumption. Looking to the immense development which the transmission of energy may be expected to undergo in the coursc of the next few decades, a convenient and manageable method of receiving large quantities of transmitted energy, and of holding it in readiness until wanted, must be of prime importance.

It was in view of such applications as these that the invention of the storage battery by Faure was hailed with enthusiasm by the highest scicntific authority in Great Britain; while the public, jumping to the conclusion that a thing for which so many uses could be instantly found must needs be a profitable investment, hastened to provide money, not for commencing careful experiments and perfecting the arrangement, which would have been wise, but for manufacturing tons of apparatus in its first crude, immature, and untried form. Some day it may perhaps be recognised that because it can be shown that a thing will be extremely useful when perfect it does not follow that it has already attained that perfection, that indeed probabilities based on historical developments are enormously against such abnormal and instantaneous maturity, and that the careful nursing and rearing necessary to healthy maturity are better given in the seclusion of laboratory and study than in the excited and heated atmosphere of the Stock Exchange. It is doubtless recognised already that all preliminary operations are better conducted on a scale smaller than the wholesale manufacturing one. In developing a new industry there are scientific difficulties to be overcome, and there are manufacturing difficulties. By scientific difficulties we mean such as the determination of weak points, the best ways of strengthening them, and generally the discovery of theoretically the best modes of effecting the object in view: manufacturing difficulties begin with questions of expediency and economy-how most cheaply and satisfactorily to carry out the indications of theory, to obtain this or that material-and include the organisation of a system of manufacture, of division of libour, of machine tools, which shall enable the work to be done with economy, security, and despatch. Over-haste in the preliminary stages causes both these sets of difficulties to be tackled together, and so throws a grievous burden on both adviser and manager. All these untoward conditions have storage batteries experienced; and to say they have not fulfilled the hopes of their early promoters is no more than to say that those hopes were untimely and unreasonable. The period of maturity has been undoubtedly delayed by injudicious treatment, but its ultimate attainment seems to us inevitable; and it is at present a matter of opinion how nearly it has already been reached: certainly great steps towards it have been made. Let us inquire what some of the difficulties encountered have been, and it will be seen that, formidable as some of them are, they belong essentially to an infantile stage, and are not suggestive of constitutional debility.

The first form of manufacture consisted in rolling up sheets of lead and composition, with trousering to keep them separate. The difficulties found were that the coatings would not adhere, but became detached in large flakes; that the trousering got corroded through and permitted short circuiting; and that free circulation of fluid being impossible, the acid became exhausted in some places and concentrated at others, and thus every sort of irregularity began. Now regularity or uniformity is of the most vital and fundamental importance in any form of battery. If any part of a plate is inactive, that part is better away; if any plate in a cell is inactive, it is better away ; and if any cells of a battery are inactive, they are infinitely better away. The rolling or coiling up of the sheets being found awkward in practice and liable to detach the coatings, flat plates came to be used, then perforated plates, and then cast grids; these last having such large hole space that they held enough composition, and held it securely enough, to enable the trousering or intermediate porous material to be dispensed with. This was an cvident step in advance: free circulation of the liquid became possible, and could be assisted by stirring; there was nothing to corrode except the plates themselves, and the composition, being in the cells or holes of the grid, might be reasonably expected to adhere. So far expectation was not altogether belied. The adhesion was not perfect, it was true, and pieces of composition sometimes fell out of the holes, especially if too powerful currents were passed throtigh the cell, but still it was much better than it had been; and if the plates were well filled, properly formed, and fairly treated, the composition adhered extremcly well and securely. 'The circulation of the liquid was not automatically perfect either, but mechanical agitation could be readily applied; without it the acid near the bottom of the cells tended to become more concentrated than that near the top, not by reason of gravitation 
undoing diffusion, which is impossible, but because during each charging fresh acid is formed, and in great part falls to the bottom in visible streams. Another great advantage was that some amount of inspection of the plates became possible, and experience as to the actual behaviour and appearance of the plates, began to be accumulated. And painfully varied that experience was. Every variety of extraordinary behaviour which could be suggested as probable, and a good many which no one could possibly have imagined beforehand, made their appearance. The hundreds of tons of batteries made at this period doubtless enabled these unpleasant experiences to be more rapidly acquired than would have been done on a small scale, but it was a costly series of experiments. However, the experiments were made, the public involuntarily assisted in the acquisition of experience, and, caring less for knowledge than for marketable commoditics, they expressed dissatisfaction at the result. Many of these incipient difficulties are now overcome by the manufacturers, but the great dislike of the public to involuntary experiments, and the shock which their confidence underwent on being unexpectedly called upon to participate in research, have not yet altogether abated.

The main difficulty now experienced was how to keep the plates from touching. They might be put in wooden frames, or elastic bands might be stretched round each of them, and if they would only keep flat it was impossible they should touch unless the composition should drop out of the holes. Sometimes the composition did drop out of a hole, and bridge across the interval between two plates, but the more common and more fatal experience was that the plates would not keep straight. In a few months the positives were found to swell, and as they swelled to bucklc-to buckle and twist into every variety of form, so that elastic bands, wooden frames, and every other contrivance failed altogether to prevent short-circuiting. The cause of the buckling is of course irregular and one-sided swelling, and the cause of the swelling is apparently the gradual peroxidation and sulphating of the material of the bars of the lead grid, which occupy less room as metallic lead than as oxide or salt. As the bars swell, they press on the inclosed composition, occasionally driving it out, but more frequently, and with properly made and treated plates universally, distending themselves and stretching the whole medial portion of the plate. The edge or frame of the grid is stronger than the middle bars, and is not so easily stretched; in a good and uniformly worked plate it does stretch, and an old positive plate is some quarter of an inch bigger every way than a new one, but if one face of the plate is a trifle more active than the other, it is very plain that the most active side will tend to become convex; and buckling once begun very easily goes on. To cure it two opposite plans have been tried: one is to leave the plates as free and unconstrained as possible, hanging free it may be from two points, thin, and with crinkled or crimped margins to allow for expansion; the other is to make them thick and strong, with plentiful ribs for stiffness, and besides to clamp them up one to another as tightly as may be, and thus in mechanical ways to resist buckling and distortion. I do not know that any one could say for certain beforehand which of these two plans would bc likely to answer best, but practice is beginning to reply in favour of the latter, and well braced plates of fair thickness show no unmanageable tendency to buckle. It must be remembered that no material can buckle with a force greater than that necessary to restore it to flatness, and this force in the case of lead is very moderate. Hence it may be fairly hoped to overcome and restrain all exuberances by suitable clamps and guides arranged so as to permit flat and even growth, but to check all lateral warpings and excrescences.

Uniformity of action is still essential, especially if all the plates in a cell are clamped together. Plates mechani- cally treated alike ought to be electrically so treated also, and it is impossible to keep a set of plates working satisfactorily together unless the contact of each is thoroughly and equally good, so that each may receive its fair share of current. Defects of contact have.been a fruitful source of breakdown and irregularity. Clamps and screws of every variety have been tried, but the insidious corroding action of nascent oxygen exerted through the film of acid which by spray and creeping forms and concentrates on the lugs-this corroding action crawls between the clamped surfaces, gradually destroys all perfect contact, and sometimes produces almost complete insulation. Contacts on the negative plates give but little trouble ; contacts on the positives have taxed a great amount of patience. Lead contacts " burned," i.e. melted, not soldered on, are evidently less liable to corrosion than brass or copper fittings, or than any form of clamp, but they are apt to be somewhat clumsy if of sufficient conductivity, and moreover they are awkward to undo again, and somcwhat troublesome to do. However they have proved themselves so decidedly the best that now no other contacts will be used, and their re-introduction has been followed by a marked improvement in the behaviour of the cells. So long as contact with one plate was better than with another, a thing quite possible to happen without any difference being perceptible to the eye, so long was it possible for one or two plates to remain almost wholly inactive while another one or two received far more than their share of current, and became distended, warped, overcharged, and ultimately crumbled away. If one or two plates in a cell are black, and giving off torrents of gas, while the rest are brown and idle-looking, it is pretty fair evidence of irregular and insufficient contact, or else of some great discrepancy in the age or make of the plates. This point also is one that was not attended to in the early stages of manufacture ; plates were made for stock, and cells were made up with plates of all ages selected at random from the store. Directly uniformity is perceived to be essential, this is recognised as obviously bad. Plates intended to work together should be of the same age and make, and inasmuch as keeping does not improve them, the best plan is not to make for stock, but to keep material ready, and then quickly make up as wanted. Plates in work deteriorate slowly, but they are wearing out in the fulfilment of their proper function; plates in idleness deteriorate as quickly, and they are rusting out in fulfilment of no function at all. Worn-out plates, however, are by no means valueless. Lead material has a well recognised price, and if attention were given to the subject, it: is probable that decrepit and useless plates might be made to yield a very large pcrcentage, if not the whole, of their original lead. For it must be remembered that plates deteriorate not by waste but by accretion: an old plate contains as much lead as a new one, but it contains it with the addition of oxygen and sulphion; no longer a tenacious coherent frame, but a crumbling mass of incoherent powder.

The age of plates is a point of vital interest, though but little is known as to the possibilities in this direction at present. A year may be regarded as a fair average age at the present time; but this is a low rather than a high estimate. Thick plates are found to last far longer than thin, which is only natural when it is remembered that the wcaring out is due to corrosion, that corrosion proceeds mainly from the surface inwards, and that the internal portions of a thick plate are to a great extent protected by the mass of superincumbent material. If it can be shown, as we understand it can, (I) that the cost of materials is far more than the cost of manufacture ; (2) that the worn-out material has a market value not incomparably less than the original; and (3) that the frequency with which plates have to be renewed is not such as to cause much inconvenience; then we hold that the first stage of the durability difficulty has been over- 
come. Much more may be hoped for in this direction as experience increases, and it is not extravagant to hope that a well-ribbed, properly-clamped, and fairly-treated thick plate may last as long as five years before it becomes disintegrated.

It is evident, however, that in a region where pure experiment is pre-eminent, and where the units of time are months and years, instead of hours and days, the accumulation of experience is a slow and tedious process. It is no use making statements involving periods of five years when no one has had the present improved form in use for so much as six months. Nevertheless it is possible to sce that the present cells are better than their predecessors; and as their predecessors have lasted in good condition for a year and more it is not presumptuous to indulge in well-founded hopes. Many of the difficulties connected with the early forms of battery were aggravated by Utopian notions concerning internal resistance and compactness. The internal resistance of a cell was so beautifully small, that the manufacturers were tempted to diminish it still further by putting the plates far too close together. An eighth or tenth of an inch interval is well enough if the plates had been hard rigid slabs of perfect flatness; but it was madness to pack flexible lead plates full of composition certain to swell and liable to drop out so near together as this. Security and dependableness were sacrificed to a natural desire for sudden and Utopian perfection. We may hope that these lessons have been profited by, and that the manufacturers perceive that confidence and security are the first conditions of success, and that minutiac as to the number of noughts before the significant figures in the specification of resistance begin, though those also are of importance in their turn, are yet of quite secondary consideration. Moreover, this packing of the plates so closely did not really do much to secure the result desired; the greater part of the resistance of half run-down cells is not in the liquid between the plates, but in the surface or scum separating cach plate, and especially each negative platc, from the liquid, and hence putting the plates a safe distance, say a quarter or one-third of an inch, apart exerts an effect on the total resistance which is certainly far more than compensated by the ready opportunity thus afforded for access by both sight and touch. The old opaque boxes chock full of plates, with slight india-rubber bands between them, were started and left to Providence. No one could see what went on, nor could one readily get at anything to rectify what was wrong. In the present glass boxes properly arranged on accessible shelves with only plugs or studs between the plates, clear vision through the cell in any direction is easy, and accidental obstruction not only very seldom occurs but if it does it can without difficulty be seen and removed. But it must be granted that these boxes are less compact than their predecessors, and for some purposes, such as locomotion, compactness is of the first importance. Most true, for some purposes. It is not to be supposed that one type of cell will answer every possible demand. A dynamo to be highly efficient must have a large and massive field magnet, but in some places bulk and weight are fatal objections, and in these places smaller and more compact dynamos may be more suitable : something, however, must be given up to secure the required lightness and compactness, some sort of compromise must be effected. Just so with cells : we can point out what is theoretically the best form, and this form may, for large stationary electric light or power installation, be actually the most suitable ; but we may also see that for boats, for tramcars, and for fish torpedoes, some very different and far more compact form may be quite essential.

Efficiency, Durability, Economy, Compactness : it may not be possible to attain all these at once-if it were, there would be small room for discussion-but sometimes one and sometimes another will be the pressing necessity, and manufacturers of storage batteries, like manufacturers of dynamos, must be prepared with forms suited to various needs.

We have spoken mainly of difficulties connected with the positive plates, and have said nothing concerning the negatives. It is not that these are not susceptible of improvement, but their faults have been of a less imperious and obtrusive nature. They are not perfect, but they do fairly well, and there has been little need to worry much about them, until the extraordinary behaviour of positives had been taken in hand and checked. The time is coming to attend to these also. They fail not from exuberance, but from inertness. As they grow old, they do not swell, and warp, and burst, and crumble, like the positives, but they grow quietly hoary, and serenely decay. The composition in a worn-out negative consists of white sulphate through and through, but the frame remains intact, and it consequently never falls to pieces, nor does it swell. Impurities in the acid used tell upon a negative plate-nitric acid is fatal. Acid much too weak or very much too strong is also deleterious, and idleness is bad. The difficulties connected with negatives mostly depend on their aggravating property of always requiring a quite opposite treatment to positives. The less a positive is formed and overcharged the better. A negative delights in complete formation and frequent overcharge. In recognition of this it is now customary to form them separatcly, and to give the negative a thorough dose of hydrogen without commencing the corrosion of the positive by an overdose of oxygen. When the discharge from a cell begins to flag, it is the resisting scum of sulphate that has formed over the negative plate which is responsible for the flagging. The true E.M.F. of a cell is wonderfully constant throughout the whole discharge; but the internal resistance is all the time increasing, at first very slowly, ultimately, towards the end, with a rush. One such run-down cell in the midst of a lot of others therefore obstructs the current terribly. If only a series of cells could with certainty be made to work together uniformly, if a series could behave as well as some of the cells in it, no one would have cause to complain.

Through the whole history of the manufacture, from the very beginning, a few cells here and there have always exhibited astonishing efficiency;-the aim of manufacturers may be said to be to bring all cells up to the level of a few. Much progress in this direction has been made, and it may be very fairly expected that, as uniformity is gradually attaincd, a series of cells subjected to the same treatment may behave in the same manner. Whenever this is certainly accomplished, there will have been reached a high stage of cfficiency, beyond which further progress need be only in the improvement of comparably insignificant minutiæ.

The subject of the electrical storage of energy is really one of national importance ;--it is comparatively a small matter whether this or that form of storage, or this or that company of manufacturers, succeeds in bringing out the permanent form. It sometimes unfortunately happens that enterprising pioneers only clear the way, and retire just in time for other men to come in and reap the fruits of their labours. So much capital and so much labour have been already expended in the effort to bring storage batteries to perfection, so great progress has been made, and so apparently small are the steps which yet remain to be accomplished, that we may surely fairly hope that some of the original believers in their great, and as it seems to us incvitable, future may yet live to see their faith justified and their patience rewarded, and may even taste some of that so-called "substantial" reward without the hope of which great commercial enterprises would never be undertaken, and modern civilisation would have scarcely yet begun.

O. J. L. 